\title{
The Role of Knowledge Management in Enhancing Organizational Performance
}

\author{
Abdel Nasser H. Zaied \\ Vice dean for education and students affaires, College of Computers and Informatics, Zagazig University, Egypt \\ Gawaher Soliman Hussein \\ Teaching Assistant, College of Computers and Informatics, Zagazig University, Egypt \\ Mohamed M. Hassan \\ Head of Information Systems Department, College of Computers and Informatics, Zagazig University, Egypt \\ nasserhr@zu.edu.eg, nasserhr@gmail.com \\ Phone: +201008388588
}

\begin{abstract}
Knowledge management is recognized as an important weapon for sustaining competitive advantage and improving performance. The evaluation of knowledge management (KM) performance has become increasingly important since it provides the reference for directing the organizations to enhance their performance and competitiveness. This paper provides an understanding of factors that involved in implementing knowledge management concept to enhance organizational performance. Also, it provides an assessment tool that helps organizations to assess their knowledge management capabilities and identify the possible existing gaps in their knowledge management systems and suggest the possible ways to enhance organizational performance. The results show that all elements of knowledge management capabilities have a positive significant relationship with all measures of the performance at $1 \%$ level of significant; it means that there is a great correlation between knowledge management capabilities and organizational performance
\end{abstract}

Index Terms - Knowledge Management Framework; Organizational Performance; Knowledge Management Capabilities

\section{INTRODUCTION}

The twenty first century is the era of knowledge economy, in which most organizations possess knowledge that enables them to improve their performance. How does the organization enhance organizational capabilities to boost internal performance and external competitiveness is a critical issue. Many scholars had attempted to measure the contribution of the KM by different models. Gold et al. [1] examined empirically the issues of effective knowledge management from the perspective of organizational capabilities. They found that knowledge infrastructural capability and knowledge process capability are the drivers of organizational effectiveness. Lee and Choi ${ }^{[2]}$ examined the correlation between knowledge management processes and organizational creativity. They concluded that, knowledge management processes are significant predictors for organizational creativity.

Recently, Quink [3] investigated the impact of knowledge management on the organizational performance of nonprofit organizations. The results showed that there is a positive relationship between knowledge management infrastructure, knowledge management process, and organizational performance. Suzana and Kasim ${ }^{[4]}$ studied the significant role of Knowledge management practices in improving the performance of organizations. The results showed that the levels of knowledge management practices were important criteria for determining and improving organizational performance.

More recently, Chang and Chuang ${ }^{[5]}$ examined empirically the effective KM processes from the roles of infrastructure capability and business strategy on firm performance. The results confirmed the impact of KM processes on firm performance. Mills and Smith ${ }^{[6]}$ studied the impact of knowledge management resources on organizational performance. The results show that some knowledge resources (structure \& acquisition) were directly related to organizational performance, while others (technology \& culture) were not directly related to organizational performance.

Accordingly, this study analyzes the previous studies and measures knowledge management elements to investigate the correlation between knowledge management (infrastructure and processes) and organizational performance.

The remainder of this paper is organized as follows. Sections $2 \& 3$ present KM components and KM performance. Section 4 describes the research methodology, whereas Section 5 discusses the results. Finally, we conclude with summaries of this work.

\section{KNOWLEDGE MANAGEMENT}


Knowledge is not easily measured or audited, so organizations must manage knowledge effectively in order to take full advantage of the skills and experience inherent in their systems and structures as well as the tacit knowledge belonging to the employees of the organization.

\subsection{Knowledge Management Definitions}

Knowledge management (KM) has been defined in different ways in scientific literature; Wiig ${ }^{[7]}$ defined it as "a group of clearly defined process or methods used to search important knowledge among different knowledge management operations". Gupta et al. ${ }^{[8]}$ defined KM as "a process that helps organizations to find, select, organize, disseminate, and transfer important information and expertise necessary for activities. Recently, Filemon and Uriarte ${ }^{[9]}$ defined $\mathrm{KM}$ as the broad process of locating, organizing, transferring, and using the information and expertise within an organization.

\subsection{Knowledge Management Components}

Wiig ${ }^{[7]}$ stated that knowledge management aims firstly to facilitate an organization in acting intelligently, in order to secure its viability and success, and secondly to make an organization to realize the best value of its knowledge assets.

\subsubsection{Knowledge Management Infrastructure}

The knowledge management infrastructures are the mechanism for the organization to develop its knowledge and also stimulate the creation of knowledge within the organization as well as the sharing and protection of it. Many researchers discussed the knowledge management infrastructure capabilities through the following elements: technology; structure; culture and human resources as shown in Table 1.

\subsubsection{Knowledge Management Process}

The knowledge management processes is defined as the degree to which the firm creates, shares, and utilizes knowledge resources across functional boundaries ${ }^{[5]}$. Many researchers discussed the knowledge management process capabilities through the following elements: acquisitions; conversions; applications storing and protections as shown in Table 2 .

Table 1. Knowledge management infrastructure elements

\begin{tabular}{|c|c|c|}
\hline Elements & Definition & Author(s) \\
\hline Technology & $\begin{array}{l}\text { Technology refers to as the technical systems within an organization, which } \\
\text { determine how knowledge travels throughout the enterprise and how } \\
\text { knowledge is accessed. }\end{array}$ & \multirow{4}{*}{$\begin{array}{c}\text { [1], [2], [3], [5], } \\
{[6],[10],[11],} \\
{[12],[13],[14],} \\
{[15],[16],[17],} \\
{[18],[19],[20] \&} \\
{[21]}\end{array}$} \\
\hline Structure & $\begin{array}{l}\text { Structure refers to the extent of an organization's structural disposition toward } \\
\text { encouraging knowledge-related activities. }\end{array}$ & \\
\hline Culture & $\begin{array}{l}\text { Culture is a set of shared values, norms and beliefs, mainly implicit, that the } \\
\text { members of an organization possess. }\end{array}$ & \\
\hline $\begin{array}{l}\text { Human } \\
\text { resources }\end{array}$ & $\begin{array}{l}\text { Human resources describe the extent to which employees specialize in a } \\
\text { particular domain and demonstrate the capability of applying that knowledge } \\
\text { to interact with others. }\end{array}$ & \\
\hline
\end{tabular}

Table 2. Knowledge management process elements

\begin{tabular}{|c|c|c|}
\hline Elements & Definition & Author(s) \\
\hline Acquisition & $\begin{array}{l}\text { Acquisition is a process that covers the activities of the accessibility, collecting } \\
\text { and application of acquired knowledge. }\end{array}$ & \multirow{5}{*}{$\begin{array}{lll} & {[1],[4],} & {[6],} \\
{[14],} & {[17],} & {[20],} \\
{[21],} & {[22],} & {[23],} \\
{[24],} & {[25],} & {[26]} \\
{[27] \&[28] .} & \end{array}$} \\
\hline Conversion & $\begin{array}{l}\text { Conversion is a process that converts knowledge acquired from external and } \\
\text { internal sources into useful and applicable forms to improve productivity and } \\
\text { business operations. }\end{array}$ & \\
\hline Application & $\begin{array}{l}\text { Application is the process of actual use of knowledge. The application of } \\
\text { knowledge enables organizations continuously to translate their organizational } \\
\text { expertise into embodied products. }\end{array}$ & \\
\hline Storing & $\begin{array}{l}\text { Storing is the process of keeping Knowledge within the organization and } \\
\text { includes physical resources as well as non-physical resources. }\end{array}$ & \\
\hline Protection & $\begin{array}{l}\text { Protection is the process of secure the knowledge asset and keeps it safe and } \\
\text { accessed only by authorized personnel. }\end{array}$ & \\
\hline
\end{tabular}

\section{KNOWLEDGE MANAGEMENT PERFORMANCE}

Many scholars had attempted to measure the contribution of the KM by different models. Table 3 summarized the knowledge management performance measures. 
Table 3. Knowledge management performance measures

\begin{tabular}{|l|c|}
\hline \multicolumn{1}{|c|}{ Performance measure } & Author(s) \\
\hline - Perceived usefulness & \\
\hline - Market share & \\
\hline - Profitability \& Growth rate & \\
\hline - Innovativeness & \\
\hline - Customer satisfaction [4], [5], [10], [13], \\
- Sales growth & [15], [18], [19], [21], [29], \\
- [31], [32], [33], [34], \\
[35], [36] \& [37]
\end{tabular}

\section{RESEARCH METHODOLOGY}

The main objective of this work is to study the role of knowledge management in enhancing organizational performance of some Egyptian organizations. To fulfill the objective and achieve the goal of this research work, a questionnaire was designed to collect the required information.

\subsection{Questionnaire Design}

Questionnaires are an inexpensive way to gather data from a potentially large number of respondents. The questionnaire was designed based on Gold et al. ${ }^{[1]}$ and Liao et al. ${ }^{[18]}$ models; it consists of four main parts:

- Part (I): Demographics: personal information and organization information.

- Part (II): KM infrastructure: to measure technology; culture; structure and human resource and has 24 measuring statements.

- Part (III): KM process: to measure acquisitions; conversions; application; protection and storing and has 30 measuring statements.

- Part (V): KM performance: to measure productivity; profitability; market share; sales growth; innovativeness; cost performance and competitiveness and has 14 measuring statements.

The participants were asked to rate their perception towards the knowledge management deployment level within their organizations on a five-point Likert-type scale with anchors from "5- Strongly agree" to "1Strongly disagree".

\subsection{Research Sample and Questionnaire Distribution}

Organizations under study were medium and large size organizations. The list of organizations was compiled from Cairo Chamber of Commerce (CCC), Egypt. Thirty organizations $(10$ governmental organizations, 10 private organizations and 10 public organizations) were selected randomly based on their experiences. After personal contact, fourteen organizations (5 governmental organization; 6 private organizations and 3 public organizations) were agreed to participate in the study conditioning to hide their names. To ensure full coverage of potential respondents, several meetings were hold with supervisor persons to explain the questionnaire objectives and to answer any question regarding the questionnaire. Supervisors have been asked to distribute not more than 40 copies of the questionnaire. The questionnaire has been distributed regardless the IT employee position, sex, age, education or experience.

\subsection{Data Collection}

The data were collected during the period July 2011 - October 2011. The total number of received questionnaires is 302 questionnaires out of 560. Table 4 \& Figure 1 show number of received questionnaires based on sectors, whereas Table $5 \&$ Figure 2 show number of received questionnaires based on organization types, and finally Table $6 \&$ Figure 3 show number of received questionnaires based on organization size.

Table 4. Number of responding organization based on sector

\begin{tabular}{|l|c|c|}
\hline \multirow{2}{*}{\multicolumn{1}{|c|}{ Sector }} & \multicolumn{2}{c|}{ Organizations } \\
\cline { 2 - 3 } & No. & $\%$ \\
\hline Oil (O) & 2 & $14.28 \%$ \\
\hline Information Technology (IT) & 1 & $7.14 \%$ \\
\hline Industrial (I) & 2 & $14.28 \%$ \\
\hline Services (S) & 9 & $64.28 \%$ \\
\hline Total & 14 & $100 \%$ \\
\hline
\end{tabular}

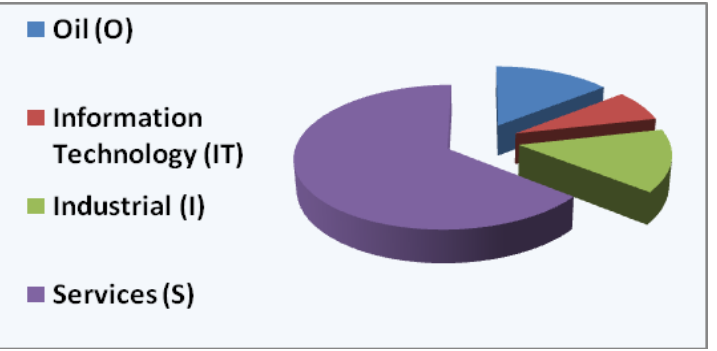

Figure 1. Number of responding organization based on sector

Table 5. Number of responding organization based on organization type

\begin{tabular}{|l|l|l|}
\hline \multirow{2}{*}{$\begin{array}{l}\text { Organization } \\
\text { type }\end{array}$} & Organizations \\
\cline { 2 - 3 } & No. & $\%$ \\
\hline Governmental & 5 & $35.71 \%$ \\
\hline private & 6 & $42.86 \%$ \\
\hline public & 3 & $21.43 \%$ \\
\hline Total & 14 & $100 \%$ \\
\hline
\end{tabular}




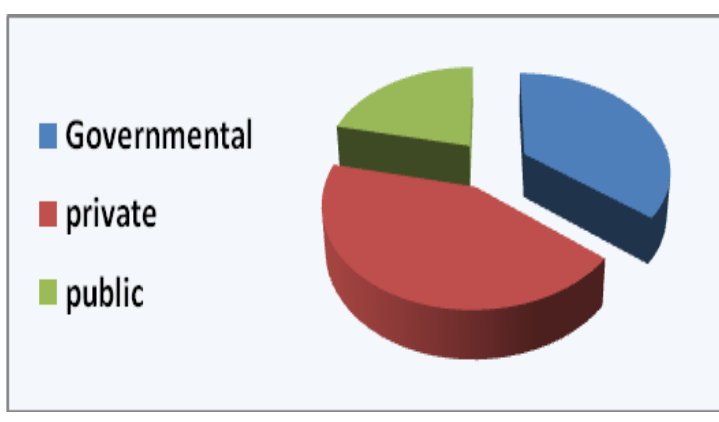

Figure 2. Number of responding organization based on organization type

Table 6. Number of responding organization based on organization size

\begin{tabular}{|l|c|c|}
\hline \multirow{2}{*}{ Organization size } & \multicolumn{2}{|c|}{ Organizations } \\
\cline { 2 - 3 } & No. & $\%$ \\
\hline Large & 10 & $71.5 \%$ \\
\hline Medium & 4 & $28.5 \%$ \\
\hline Total & 14 & $100 \%$ \\
\hline
\end{tabular}

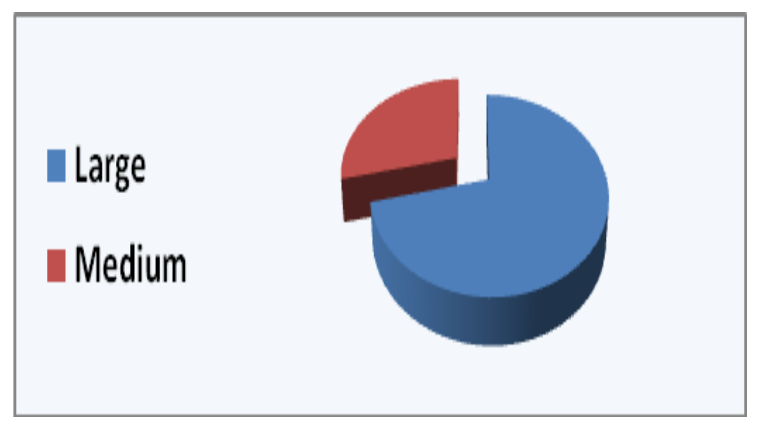

Figure 3. Number of responding organization based on organization size

\subsection{Data Analysis}

The Statistical Package for Social Sciences (SPSS 16.0) software was used to analyze the data collected. Internal consistency of scales was measured by Cronbach's alpha coefficient, if the test shows that the value of the Cronbach's Alpha equal 0.80 or above, it means the collected data are consistent (Pallant, 2005). The result of test showing the value of the Cronbach's Alpha equals to 0.903 . This confirms the reliability of the collected data (internal consistency is excellent). Also, the results show that all the nine elements of knowledge management capabilities are accepted as important elements as shown in Table 7, it means that all data collected are reliable and can be analyzed.

Table 7. "Cronbach's Alpha" if Item Deleted

\begin{tabular}{|l|c|}
\hline \multicolumn{1}{|c|}{ Item } & Cronbach's Alpha \\
\hline technology & .891 \\
\hline Culture & .890 \\
\hline Structure & .903 \\
\hline Human Resource & .893 \\
\hline Acquisitions & .889 \\
\hline Conversions & .890 \\
\hline Applications & .891 \\
\hline
\end{tabular}

\begin{tabular}{|l|l|}
\hline Protection & .889 \\
\hline Storing & .891 \\
\hline
\end{tabular}

\section{RESULTS AND DISCUSSIONS}

To explore the role of knowledge management in enhancing the performance of an organization and identify the best predictor of the organizational performance, the results were discussed according sample classifications as follows:

\subsection{Results analysis based on organization Size}

Table 8 shows participants' opinion towards knowledge management infrastructure, process and performance. The higher value was achieved by the large organizations. This means that the large organizations have better knowledge management capabilities compared to the medium organizations.

Table 8. Elements of knowledge management based on organizations Size

\begin{tabular}{|l|c|c|}
\hline \multirow{2}{*}{ Elements } & \multicolumn{2}{|c|}{ Organization Size } \\
\cline { 2 - 3 } & Large & Medium \\
\hline \multicolumn{2}{|c|}{ knowledge Infrastructure Capabilities } \\
\hline Technology & 3.76 & 3.51 \\
\hline Culture & 3.68 & 3.65 \\
\hline Structure & 3.27 & 3.35 \\
\hline Human resource & 3.74 & 3.77 \\
\hline Average & 3.61 & 3.57 \\
\hline \multicolumn{2}{|c|}{} \\
\hline Acquisitions & 3.62 & 3.56 \\
\hline Conversions & 3.66 & 3.57 \\
\hline Application Process Capabilities \\
\hline Protection & 3.73 & 3.64 \\
\hline Storing & 3.66 & 3.46 \\
\hline Average & 3.74 & 3.68 \\
\hline \multicolumn{2}{|c|}{3.68} & 3.58 \\
\hline Productivity & 4.04 & \\
\hline Profitability & 4.00 & 4.02 \\
\hline Market Share & 3.98 & 3.98 \\
\hline Sales Growth & 4.00 & 3.99 \\
\hline Innovativeness & 3.91 & 3.95 \\
\hline Cost performance & 4.00 & 3.93 \\
\hline Competitiveness & 3.99 & 3.98 \\
\hline Average & 3.01 \\
\hline
\end{tabular}

Elements showed high values are technology (3.76) as an infrastructure, storing (3.74) as a process element and productivity (4.04) as a performance element. The same results for small organization except human resources instead of technology in large organizations.

\subsection{Results analysis based on organization type}

Table 9 shows participants' opinion towards knowledge management infrastructure, process and performance. The higher value was achieved by public organizations. This means that the public organizations 
have better knowledge infrastructure capabilities compared to the private and governmental organizations.

Elements showed high values are human resources (3.85) as an infrastructure and storing (3.93) as a process element. The highest value of the organizational performance was achieved by public organizations, while the lowest value was achieved by the governmental organizations.

Productivity element showed high value in public (4.28) and governmental organizations (3.96) followed by sales growth in public (4.27), and competitiveness and market share in governmental organizations (3.89), whereas competitiveness showed high value in private organizations (4.02) followed by cost performance (3.98).

Table 9. Elements of knowledge management based on organizations type

\begin{tabular}{|c|c|c|c|}
\hline \multirow{2}{*}{ Elements } & \multicolumn{3}{|c|}{ Organization Type } \\
\hline & Gov. & Private & Public \\
\hline \multicolumn{4}{|c|}{ knowledge Infrastructure Capabilities } \\
\hline Technology & 3.64 & 3.68 & 3.79 \\
\hline Culture & 3.52 & 3.70 & 3.85 \\
\hline Structure & 3.26 & 3.47 & 3.18 \\
\hline Human resource & 3.63 & 3.78 & 3.85 \\
\hline Average & 3.51 & 3.66 & 3.67 \\
\hline \multicolumn{4}{|c|}{ knowledge Process Capabilities } \\
\hline Acquisitions & 3.55 & 3.64 & 3.66 \\
\hline Conversions & 3.55 & 3.60 & 3.85 \\
\hline Application & 3.57 & 3.74 & 3.88 \\
\hline Protection & 3.48 & 3.59 & 3.86 \\
\hline Storing & 3.61 & 3.72 & 3.93 \\
\hline Average & 3.55 & 3.66 & 3.84 \\
\hline \multicolumn{4}{|c|}{ Organizational Performance } \\
\hline Productivity & 3.96 & 3.92 & 4.28 \\
\hline Profitability & 3.86 & 3.95 & 4.22 \\
\hline Market Share & 3.89 & 3.91 & 4.20 \\
\hline Sales Growth & 3.83 & 3.92 & 4.27 \\
\hline Innovativeness & 3.76 & 3.86 & 4.21 \\
\hline Cost performance & 3.86 & 3.98 & 4.19 \\
\hline Competitiveness & 3.89 & 4.02 & 4.16 \\
\hline Average & 3.86 & 3.94 & 4.22 \\
\hline
\end{tabular}

The least important elements in private and governmental organization are innovativeness $(3.86$ \& 3.76 respectively), whereas the least important elements in public organizations are competitiveness (4.16).

\subsection{Results analysis based on organization sectors}

The relationship between knowledge management capabilities and performance will be described according to sector type. Table 10 shows participants' opinion towards knowledge management infrastructure, process and performance. The highest value of the knowledge infrastructure capabilities was achieved by the IT sector (4.33) followed by Oil sector (3.65).
Table 10. Elements of knowledge management based on organizations sector

\begin{tabular}{|c|c|c|c|c|}
\hline \multirow{2}{*}{ Elements } & \multicolumn{4}{|c|}{ Sector } \\
\hline & $\mathrm{O}$ & IT & I & $\mathrm{S}$ \\
\hline \multicolumn{5}{|c|}{ knowledge Infrastructure Capabilities } \\
\hline Technology & 4.35 & 4.34 & 3.40 & 3.68 \\
\hline Culture & 3.54 & 4.39 & 3.59 & 3.64 \\
\hline Structure & 3.04 & 4.22 & 3.32 & 3.21 \\
\hline Human resource & 3.69 & 4.36 & 3.61 & 3.74 \\
\hline Average & 3.65 & 4.33 & 3.48 & 3.57 \\
\hline \multicolumn{5}{|c|}{ knowledge Process Capabilities } \\
\hline Acquisitions & 3.31 & 4.19 & 3.50 & 3.60 \\
\hline Conversions & 3.12 & 4.30 & 3.56 & 3.63 \\
\hline Application & 3.43 & 4.38 & 3.74 & 3.64 \\
\hline Protection & 3.44 & 4.25 & 3.64 & 3.54 \\
\hline Storing & 3.54 & 4.33 & 3.68 & 3.69 \\
\hline Average & 3.37 & 4.29 & 3.63 & 3.62 \\
\hline \multicolumn{5}{|c|}{ Organizational Performance } \\
\hline Productivity & 3.71 & 4.35 & 3.94 & 4.06 \\
\hline Profitability & 3.54 & 4.43 & 3.88 & 4.02 \\
\hline Market Share & 3.46 & 4.50 & 3.87 & 4.01 \\
\hline Sales Growth & 3.57 & 4.53 & 3.94 & 3.97 \\
\hline Innovativeness & 3.64 & 4.60 & 3.91 & 3.87 \\
\hline Cost performance & 3.64 & 4.48 & 3.92 & 3.99 \\
\hline Competitiveness & 3.71 & 4.40 & 3.97 & 4.01 \\
\hline Average & 3.61 & 4.47 & 3.92 & 3.99 \\
\hline
\end{tabular}

The least value was achieved by the Industry sector (3.48). The largest value of knowledge process was achieved by the IT sector (4.29) followed by Industry sector (3.63), whereas the lowest value was achieved by the Oil sector (3.37). This means that the IT sector have better knowledge process capabilities compared to the Oil sector.

The highest value of organizational performance was achieved by the IT sector (4.47) followed by Services sector (3.99), whereas the least value was achieved by the Oil sector (3.61). This means that the IT sector have the best organizational performance compared to the other three sectors. Innovativeness element showed high value in IT sector (4.60) followed by sales growth (4.53), whereas productivity showed high value in Services sector (4.06) followed by profitability (4.02). Competitiveness showed high value in Industry sector (3.97) followed by productivity and sales growth (3.94). Competitiveness and productivity showed high value in Oil sector (3.71) followed by and innovativeness (3.64).

\subsection{Level of adopting knowledge management}

The mean value was conducted to measure the use of knowledge management and to determine the extent to which element of knowledge management capabilities (infrastructure and process) is implemented in the Egyptian organizations. Table 11 shows that knowledge process capabilities have higher value (3.65) whereas; knowledge infrastructure capabilities have (3.60). These results mean that the two knowledge management capabilities components are implemented with mean over 3.00 . 
The detailed results show that "Human Resource" has the highest mean value (3.75) along knowledge infrastructure elements, whereas; Structure has the lowest mean value (3.3). In knowledge process; Storing has the highest mean value (3.72) and Protection and Acquisitions have lowest mean value (3.60). This indicates that Egyptian organizations pay attention on storing process for knowledge by hiring qualified human resources, but organizations should put more effort in improving the other dimensions like Structure, Protection, and Acquisitions.

Table 11. Mean and standard deviation

\begin{tabular}{|c|c|c|}
\hline Items & Mean & $\begin{array}{c}\text { Std. } \\
\text { Deviation }\end{array}$ \\
\hline Knowledge Infrastructure & 3.60 & 0.552 \\
\hline Technology & 3.69 & 0.800 \\
\hline Culture & 3.67 & 0.675 \\
\hline Structure & 3.30 & 0.738 \\
\hline Human Resource & 3.75 & 0.600 \\
\hline Knowledge process & 3.65 & 0.554 \\
\hline Acquisitions & 3.60 & 0.640 \\
\hline Conversions & 3.64 & 0.706 \\
\hline Applications & 3.70 & 0.662 \\
\hline Protections & 3.60 & 0.680 \\
\hline Storing & 3.72 & 0.630 \\
\hline
\end{tabular}

In general, the results show that there is a small difference in implementation between knowledge infrastructure and process (the standard deviation values ranging from 0.6 to 0.8 ).

To find out the development opportunities (weaknesses), Table 12 sums up the most two factors that have the highest and lowest score in each sector. Structure is prevailing in all sectors as the weakest element along the nine factors.

Table 12. Weakest and strongest factors

\begin{tabular}{|c|l|l|}
\hline Sector & The strongest elements & \multicolumn{1}{c|}{$\begin{array}{c}\text { The weakest } \\
\text { element }\end{array}$} \\
\hline O & $\begin{array}{l}\text { Technology (4.35) } \\
\text { Human resource (3.69) }\end{array}$ & $\begin{array}{l}\text { Structure (3.04) } \\
\text { Conversion (3.12) }\end{array}$ \\
\hline IT & $\begin{array}{l}\text { Culture (4.39) } \\
\text { Application (4.38) }\end{array}$ & $\begin{array}{l}\text { Acquisition (4.19) } \\
\text { Structure (4.22) }\end{array}$ \\
\hline I & $\begin{array}{l}\text { Application (3.74) } \\
\text { Storing (3.68) }\end{array}$ & $\begin{array}{l}\text { Structure (3.32) } \\
\text { Technology (3.40) }\end{array}$ \\
\hline S & $\begin{array}{l}\text { Human resource (3.74) } \\
\text { Storing (3,69) }\end{array}$ & $\begin{array}{l}\text { Structure (3.21) } \\
\text { Protection (3.54) }\end{array}$ \\
\hline
\end{tabular}

\subsection{Role of knowledge management in enhancing organizational performance}

To explore the role of knowledge management in enhancing the performance of an organization and to identify the best predictor of the organizational performance, multiple regression analysis was used to analyze the results.
The results show that knowledge management capabilities (infrastructure and process) explained 48 percent $\left(\mathrm{R}^{2}=0.48\right)$ of the variance in the organizational performance. This confirms the effect of knowledge management capabilities elements in the organizational performance. The results also show positive relationship between knowledge management and organization performance $(\mathrm{R}=0.69)$ as shown in Table 13.

Table 13. Regression results

\begin{tabular}{|c|c|c|c|c|c|}
\hline Model & $\begin{array}{l}\text { Sum of } \\
\text { Squares }\end{array}$ & df & $\begin{array}{c}\text { Mean } \\
\text { Square }\end{array}$ & $\mathrm{F}$ & Sig. \\
\hline Regression & 8749.154 & 9 & 972.12 & 29.414 & .000 \\
\hline Residual & 9650.462 & 292 & 33.050 & & \\
\hline Total & 18399.616 & 301 & & & \\
\hline \multicolumn{3}{|c|}{$\mathrm{R}=69 \%$} & $=0.48$ & & \\
\hline
\end{tabular}

Storing element shows high significant influence on organization performance $(\beta=0.686, t=5.080, p<0.01)$, followed by Human Resource $(\beta=0.268, t=2.048, p<$ $0.05)$, whereas the other elements are not significant as shown in Table 14. In addition, these results are confirmed with the results of (t-test) whereas the two elements of knowledge management capabilities have statistical significant effect on organization performance.

To find out the correlation between elements of knowledge management capabilities and organization performance, Pearson correlation was used. Pearson's correlation is the most familiar measure of dependence between two quantities. It is obtained by dividing the covariance of the two variables by the product of their standard deviations ${ }^{[38]}$.

Table 15 shows that all elements of knowledge management capabilities have a positive significant relationship with all measures of the performance at $1 \%$ level of significant.

Table 14. Statistical significant for independent variables (ttest)

\begin{tabular}{|l|c|c|c|}
\hline $\begin{array}{c}\text { Elements of knowledge } \\
\text { management } \\
\text { (independent variable) }\end{array}$ & $\beta$ & $\mathrm{T}$ & Sig. \\
\hline Storing & .686 & 5.080 & .000 \\
\hline Human Resource & .268 & 2.048 & .041 \\
\hline Conversions & .237 & 1.934 & .054 \\
\hline Culture & .141 & 1.189 & .235 \\
\hline Applications & .134 & 1.026 & .306 \\
\hline Technology & .132 & 1.491 & .137 \\
\hline Protection & .129 & .964 & .336 \\
\hline Structure & -.058 & -.638 & .524 \\
\hline Acquisitions & .010 & .080 & .936 \\
\hline
\end{tabular}


Table 15. Correlation coefficients between knowledge management capabilities and performance

\begin{tabular}{|c|c|c|c|c|c|c|c|}
\hline Performance measures & 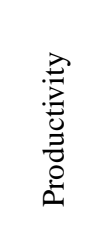 & 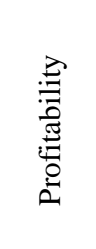 & 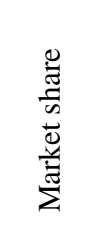 & 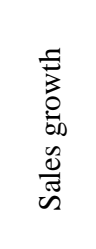 & 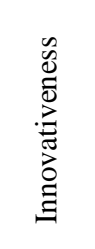 & 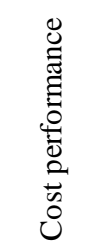 & $\begin{array}{l}\mathscr{0} \\
\stackrel{0}{0} \\
\stackrel{\Xi}{\Xi} \\
\stackrel{0}{0} \\
\stackrel{0}{0}\end{array}$ \\
\hline Technology & $.378 * *$ & $.390 * *$ & $.403 * *$ & $.386^{* *}$ & $.386 * *$ & $.255^{* *}$ & $.240 * *$ \\
\hline Culture & $.382 * *$ & $.430 * *$ & $.438 * *$ & $.399 * *$ & $.413 * *$ & $.345^{* *}$ & $.378^{* *}$ \\
\hline Structure & $.222 * *$ & $.289 * *$ & $.330 * *$ & $.256^{* *}$ & $.277 * *$ & $.218^{* *}$ & $.259 * *$ \\
\hline Human Resource & $.349 * *$ & $.359 * *$ & $.365 * *$ & $.432 * *$ & $.491 * *$ & $.377 * *$ & $.427 * *$ \\
\hline Acquisitions & $.372 * *$ & $.398 * *$ & $.384 * *$ & $.392 * *$ & $.372 * *$ & $.349 * *$ & $.330 * *$ \\
\hline Conversions & $.369 * *$ & $.433 * *$ & $.422 * *$ & $.481 * *$ & $.473 * *$ & $.459 * *$ & $.410 * *$ \\
\hline Applications & $.343 * *$ & $.425 * *$ & $.398 * *$ & $.430 * *$ & $.480 * *$ & $.440 * *$ & $.417 * *$ \\
\hline Protections & $.412 * *$ & $.465 * *$ & $.407 * *$ & $.463 * *$ & $.514 * *$ & $.440 * *$ & $.436 * *$ \\
\hline Storing & $.436 * *$ & $.518 * *$ & $.533 * *$ & $.559 * *$ & $.527 * *$ & $.509 * *$ & $.446 * *$ \\
\hline
\end{tabular}

\section{CONCLUSIONS}

This study investigated the role of knowledge management in enhancing the organizational performance in some Egyptian organizations and addressed its relationship with performance improvement. Also, it measured the level of knowledge management capabilities and addressed the relationship between knowledge management capabilities and organizational performance measures. Results of correlation analysis show significant relationship between knowledge management elements and performance improvement measures, which in turn represented the quality of organizational knowledge that was utilized in a wide variety of decision-makings in the firm. Thus, if the quality of organizational knowledge is good, it can be conclude that management performance improves significantly.

The study findings shed light on the following points. First, besides providing empirical evidence to the correlation between knowledge management and organizational performance, this study shows high positive correlation between the following couple of elements and measures: technology \& market share; culture \& profitability; structure \& market share; human resource \& innovativeness; acquisitions \& profitability; conversions \& sales growth; applications $\&$ innovativeness; protections \& profitability and storing \& sales growth. These results are consistent with findings of previous research like Quink ${ }^{[3]}$; Suzana and Kasim [4]; Chang and Chuang [5]; AlBusaidi \& Olfman ${ }^{[39]}$ and Zaied ${ }^{[40]}$. Second, factors like organization type and size affect level of adopting knowledge management; whereas factor like sector type affects the role of knowledge management in enhancing the organizational performance. Third, many organizations still view knowledge management as launching some software programs without adequate consideration of their organizational characteristics, this study brings to attention the importance of focusing on creating a knowledge environment that is made up of appropriate technology; cultural; structural and human resources.

Future research is needed to further investigate the relationship between degrees of knowledge management implementation within an organization and corresponding increases in organizational performance.

\section{REFERENCES}

[1] Gold A., Malhotra A. \& Segars A., (2001), "Knowledge management: an organizational capabilities perspective" Journal of Management Information Systems, 2001, 18(1): 185-214.

[2] Lee H. \& Choi B., "Knowledge management enablers, processes, and organizational performance: An integrative view and empirical examination", Journal of Management Information Systems, 2003, 20(1): 179-228.

[3] Quink U., "An Exploration of knowledge management and intellectual capital in a nonprofit organization context", master thesis, the Queensland University of Technology, 2008.

[4] Suzana R. \& Kasim R. (2010) "The Relationship of Knowledge Management Practices, Competencies and the Organizational Performance of Government Departments in Malaysia", International Journal of Human and Social Sciences, 2010, 5(4): 219:225.

[5] Chang T. \& Chuang S., "Performance implications of knowledge management processes: Examining the roles of infrastructure capability and business strategy", Expert Systems with Applications, 2011, 38: 6170-6178.

[6] Mills A. \& Smith T., "Knowledge management and organizational performance: a decomposed view", Journal of Knowledge Management, 2011, 15(1): 156-171.

[7] Wiig K., "Knowledge management foundationsthinking about thinking-how people and organizations create, represent, and use 
Knowledge”, 1995, Texas: Schema Press Arlington.

[8] Gupta B., Iyer L. \& Aronson, J., (2000), "Knowledge management: practices and challenges", Industrial Management \& Data Systems, 2000, 100(1): 17-21.

[9] Filemon A. \& Uriarte J., "Introduction to Knowledge Management", ASEAN Foundation, Jakarta, Indonesia, 2008.

[10] Liao C. \& Chuang S., "Exploring the Role of Knowledge Management for Enhancing Firm's Innovation and Performance", 39 $9^{\text {th }}$ Hawaii International Annual Conference on System Sciences, USA, 2006: 1-10.

[11] Yeh Y., Lai S. \& Ho C., "Knowledge management enablers: a case study", Industrial Management \& Data Systems, 2006, 106(6): 793-810.

[12] Davidson P. \& Griffin R., "Management", $3^{\text {rd }}$ Australasian edition. Milton, 2006, john Wiley \& Sons Australia.

[13]Lee Y. \& Lee S., "Capabilities, Processes, and Performance of Knowledge Management: A Structural Approach", Human Factors and Ergonomics in Manufacturing, 2007, 17(1): 21-41.

[14]Zaim H., Tatoglu E. \& Zaim S., "Performance of knowledge management practices: a causal analysis", Journal of Knowledge Management, 2007, 11(6): 54-67.

[15] Chang T. \& Chuang S., "Performance Effects of Knowledge Management: Corporate Management Characteristics and Competitive Strategy Enablers", Asian Journal of Management and Humanity Sciences, 2009, 4(4): 181-199.

[16] Nguyen Q., Neck P., \& Nguyen T., "The Critical Role of Knowledge Management in Achieving and Sustaining Organizational Competitive Advantage", International Business Research, 2009, 2(3): 3-16.

[17]Fan Z., Feng B., Sun Y. \& Ou W., "Evaluating knowledge management capability of organizations: a fuzzy linguistic method", Expert Systems with Applications, 2009, 36: 3346-3354.

[18] Liao C., Wang H., Chuang S., Shih M., \& Liu C., "Enhancing knowledge management for R\&D innovation and firm performance: An integrative view", African Journal of Business Management, 2010, 4(14): 3026-3038.

[19] Theriou N., Maditinos D., \& Theriou G., "Knowledge Management Enabler Factors and Firm Performance: An empirical research of the Greek medium and large firms". International Conference on Applied Business and Economics, Technological Educational Institute of Kavala, Kavala, Greece, 2010: 1-20.

[20] Smith T., Mills A. \& Dion P., "Linking Knowledge Management Capabilities to the Business Strategy for Organizational Effectiveness", International Journal of Knowledge Management, 2010, 6(3): 22-43.
[21] Aujirapongpan S., Vadhanasindhu P., Chandrachai A. \& Cooparat P., "Indicators of knowledge management capability for KM effectiveness", The journal of information and knowledge management systems, 2010, 40(2): 183-203.

[22] Zahra S. \& George G., "Absorptive capacity: A review, reconceptualization, and extension", Academy of Management Review, 2002, 27(2): 185-203.

[23] Weisberg R. "Expertise and reason in creative thinking: evidence from case studies and the laboratory". In: Kaufman J. \& Baer J, "Creativity and Reason in Cognitive Development. Cambridge", Cambridge University Press; 2006.

[24] Daud S. \& Yusuf W., "An Empirical Study of Knowledge Management Processes in Small and Medium Enterprises", Communications of the IBIMA, 2008, 4: 169-177.

[25] Lee L. \& Sukoco B., "The effects of entrepreneurial orientation and knowledge management capability on organizational effectiveness in Taiwan: the moderating role of social capital', International Journal of Management, 2007, 24(3): 549-573.

[26] Cui A. Griffith D. \& Cavusgil S., "The Influence of Competitive Intensity and Market Dynamism on Knowledge Management Capabilities of MNC Subsidiaries", Journal of International Marketing, 2005, 13(3): 32-53.

[27] Chan I. \& Chao C., "Knowledge management in small and medium-sized enterprises", Communications of the ACM, 2008, 51(4): 83-88.

[28] Yli-Renko H., Autio E\& Sapienza H., "Social capital, knowledge acquisition, and knowledge exploitation in young technology-based firms", Strategic Management Journal, 2001, 22(6): 587613.

[29] Ribiere M., \& Sitar S., "Critical role of leadership in nurturing a knowledge-supporting culture", Knowledge Management Research \& Practice, 2003, 1(1): 39-48.

[30]Lee K., Lee S., \& Kang I., "KMPI: measuring knowledge management performance. Information \& Management, 2005, 42(3): 469-482.

[31] Lin C. \& Tseng S., "Bridging the implementation gaps in the knowledge management system for enhancing corporate performance", Expert Systems with Applications, 2005, 29(1): 163-173.

[32] Anantatmula V. \& Kanungo S., "Structuring the underlying relations among the knowledge management outcomes", Journal of Knowledge Management, 2006, 10(4): 25-42.

[33] Li E., Chen J. \& Huang Y., "A framework for investigating the impact of IT capability and organizational capability on firm performance in the late industrializing context", Int. J. Technology Management, 2006, 36(3): 209-229.

[34] Tay W., "Enhancing Organizational performance towards Business Profitability", KM Conference, Malaysian Institute of management, 2007:1-15. 
[35] Harrim H. "Learning Organization and Organizational Performance Relationship: Empirical Study of Pharmaceutical Firms In Jordan", Jordan Journal of Business Administration, 2010, 6(3): 405-424.

[36] Chen M. Huang M. \& Cheng Y., "Measuring knowledge management performance using a competitive perspective: An empirical study", Expert Systems with Applications, 2009, 36: 84498459.

[37]Zack M., McKeen J. \& Singh S., "Knowledge management and organizational performance: an exploratory analysis", Journal of Knowledge Management, 2009, 13(6): 392-409.

[38] Rodgers J. \& Nicewander W., "Thirteen ways to look at the correlation coefficient", The American Statistician, 1988, 42(1): 59-66.

[39] Al-Busaidi K. \& Olfman L., "An investigation of the determinants of knowledge management systems success in Omani organizations", Journal of Global Information Technology Management, 2005, 8(3): 6-27.

[40]Zaied A., “An Integrated Knowledge Management Capabilities Framework for Assessing Organizational Performance", International Journal of Information Technology and Computer Science, 2012, (4)2: 1-10.

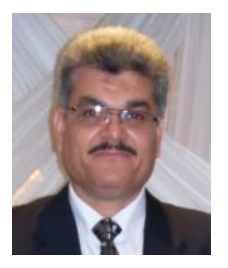

Abdel Nasser H. Zaied is a Vice-dean for education and students affairs, College of Computers and Informatics, Zagazig University, Egypt. $\mathrm{He}$ previously worked as an associate professorof Industrial Engineering, Zagazig University Egypt; an assistant professor of Technology Management, Arabian Gulf University, Bahrain; and as visiting professor at Oakland University, USA. He supervised $9 \mathrm{PhD}$. thesis and $40 \mathrm{MSc}$. thesis, and examined $34 \mathrm{MSc}$ thesis. He published nineteen research papers in International and Regional Journals and 22 research papers in International and National conferences. His areas of research are: Systems Analysis and Design; Information Security; Knowledge Management; Quality Management Systems and project Management, Electronic applications. 